episodes of metabolic acidosis and is growth retarded, whereas the 3 diagnosed in the neonatal period are thriving. All our patients were Asian and consanguinity was a feature in every case.

We thank the Department of Medical Illustration, Birmingham Children's Hospital, for the figure and Mrs Margaret Robson for secretarial assistance.

\section{References}

1 Briggs J N, Haworth J C. Liver glycogen disease. Report of a case of hyperuricaemia, renal calculi, and no demonstrable enzyme defect. Am J Med 1964; 36: 443-9.

2 Igarashi Y, Otomo H, Narisawa K, Tada K. A new variant of glycogen storage disease type 1: probably due to a defect in the glucose-6-phosphate transport system. $J$ Inherited Metab Dis 1979; 2: 45-9.

3 Chalmers R A, Ryman B E, Watts R W E. Studies on a patient with in vivo evidence of type I glycogenosis and normal enzyme activities in vitro. Acta Paediatr Scand 1978; 67: 201-7.
4 Perlman M, Aker M, Slonim A E. Successful treatment of severe type I glycogen storage disease with neonatal presentation by nocturnal intragastric feeding. $J$ Pediatr 1979; 94: 772-4.

5 Fernandes J, Huijing F, Van De Kamer J H. A screening method for liver glycogen diseases. Arch Dis Child 1969; 44: 311-7.

- Mason H H, Anderson D H. Glycogen disease. Am J Dis Child 1941; 61: 795-825.

7 Abramson H, Kurtz L D. Familial glycogen disease. Report of four fatal cases of the hepatic form of the disease in siblings of one family. Am J Dis Child 1946; 72: 510-20.

8 Schulman J L, Saturen P. Glycogen storage disease of the liver. I. Clinical studies during the early neonatal period. Pediatrics 1954; 14: 632-43.

Correspondence to Dr B A Wharton, Infant Development Unit, Birmingham Maternity Hospital, Queen Elizabeth Medical Centre, Edgbaston, Birmingham B15 2TG.

Received 19 November 1981

\title{
Liver damage in a neonate with alpha-1-antitrypsin deficiency due to phenotype PiZ null $\left(\mathrm{Z}^{-}\right)$
}

\author{
JOHN BURN, DAVID DUNGER, AND BRIAN LAKE \\ MRC Clinical Genetics Unit, Institute of Child Health and The Hospital for Sick Children, London
}

\begin{abstract}
SUMMARY An infant with neonatal liver damage had $\alpha$-1-antitrypsin deficiency, having inherited the $\mathrm{Z}$ allele from the father and the rare null allele from the mother. This indicates that while a lack of serum antiprotease predisposes to early liver disease, homozygosity for the $\mathrm{Z}$ allele is not essential.
\end{abstract}

Alpha-1-antitrypsin represents the major serum protease inhibitor and can be quantified on this basis. The use of electrophoresis and isoelectric focusing has helped to identify at least 28 allelic variants, 4 of which are associated with low levels of clinical significance; these are labelled $\mathrm{Z}, \mathrm{S}$, null, and $\mathbf{M}$ malton) in the $\mathbf{P i}$ (protease inhibitor) classification. There is a complete lack of $\alpha$-1-antitrypsin on the rare occasions that a homozygote for the null allele is identified. ${ }^{1-3}$ This allele produces no electrophoretic band; the heterozygous state can be deduced only by quantification and electrophoresis of parental blood.

The association of liver disease with $\alpha$-1-antitrypsin deficiency has been known since 1969, nearly all cases being presumed $\mathrm{ZZ}$ homozygotes. The PiZ null $\left(\mathrm{Z}^{-}\right)$heterozygote is rare. Sveger ${ }^{4}$ found $2 \mathrm{Pi} \mathrm{Z} \mathrm{Z}^{-}$neonates among 200000 screened in Sweden, one of whom was normal; the other had slightly abnormal liver function tests. We could find no previous report of severe liver damage in a child with the $\mathrm{Z}^{-}$phenotype. We report one such case.

\section{Case report}

A girl was born weighing $2.08 \mathrm{~kg}$ at 37 weeks' gestation, by caesarean section, performed because of cephalopelvic disproportion. She was the first child of unrelated parents, the mother having had 2 normal children by a previous marriage. Polyhydramnios was noted at delivery; the placenta was oedematous and weighed $750 \mathrm{~g}$.

The patient required intubation at birth and regular respirations were not established until 7 minutes had elapsed. During the first 24 hours generalised abdominal distension and hepatosplenomegaly were noted. Her indirect bilirubin, on day 3 , was $371 \mu \mathrm{mol} / 1(21.8 \mathrm{mg} / 100 \mathrm{ml})$ with a normal haemoglobin level, and one exchange transfusion was performed. A top-up transfusion was required on day 11 . She failed to thrive and was referred for investigation at 8 weeks. 
Examination showed a small, wasted child with a functional systolic murmur. The abdomen was distended and tympanic, with a liver edge $3 \mathrm{~cm}$ below, and a spleen tip palpable $3-4 \mathrm{~cm}$ below, the costal margin. Examination was otherwise normal. The haemoglobin concentration was $10.6 \mathrm{~g} / 1$, with a white cell count of $21.6 \times 10^{9} / 1$ with $49 \%$ lymphocytes, total bilirubin of $48 \mu \mathrm{mol} / 1(2.8 \mathrm{mg} / 100 \mathrm{ml})$ (direct $26 \mu \mathrm{mol} / 1(1.5 \mathrm{mg} / 100 \mathrm{ml})$ ), total protein $55 \mathrm{~g} / \mathrm{l}$, albumin $31 \mathrm{~g} / \mathrm{l}$, ALT $1266 \mathrm{IU} / \mathrm{l}$, AST 123 IU/l, 5 ' nucleotidase $44 \mathrm{IU} / 1$, and alphafetoprotein of $430 \mu \mathrm{g} / 1$. The bone age was 32-35 weeks but skeletal survey was otherwise normal. Ultrasound examination confirmed liver and splenic enlargement but the kidneys and portal veins were normal. The $\alpha-1$ globulin band was absent on plasma protein electrophoresis. The quantitative $\alpha$-1-antitrypsin level was $0.4 \mathrm{~g} / 1(40 \mathrm{mg} / 100 \mathrm{ml})$; in the mother it was $0.8 \mathrm{~g} / 1(80 \mathrm{mg} / 100 \mathrm{ml})$ and in the father $1.2 \mathrm{~g} / \mathrm{l}$ $(120 \mathrm{mg} / 100 \mathrm{ml})$. Further studies showed the $\mathrm{Z}$ pattern in the patient, $M$ pattern in the mother, and $M Z$ in the father. This indicated that the mother was a heterozygote for the $M$ and null alleles and that she had passed on the null allele to her daughter who by inference must have the $\mathrm{Z}^{-}$phenotype.

A needle liver biopsy at age 10 weeks 5 days showed preservation of the lobular architecture with prominent portal areas containing increased connective tissue. There was an accumulation of fat and diastase resistant-periodic acid-Schiff (PAS) positive globules in hepatocytes predominantly in the periportal regions, although PAS-positive droplets were found throughout the lobules (Figure). Bile pigment was present mainly within hepatocytes particularly in the centrilobular regions. Electron microscopical examination showed an accumulation of an amorphous substance within distended endoplasmic reticulum of hepatocytes.

The following investigations were normal: plasma electrolytes, calcium, phosphate, copper and zinc, thyroid function tests, urinary mucopolysaccharide, organic acid and amino-acid screens. Vacuolated lymphocytes were not detected and serologyincluding a TORCHES* screen, Paul-Bunnell, and Australia antigen-was negative. Chest $x$-ray films, barium meal, barium enema, sweat test, and electrocardiograms were normal.

\section{Discussion}

We report a child with $\alpha$-1-antitrypsin deficiency associated with the $\mathrm{Z}^{-}$phenotype who suffered

* Toxoplasma, rubella. cytomegalovirus, herpes, echo, syphilis.

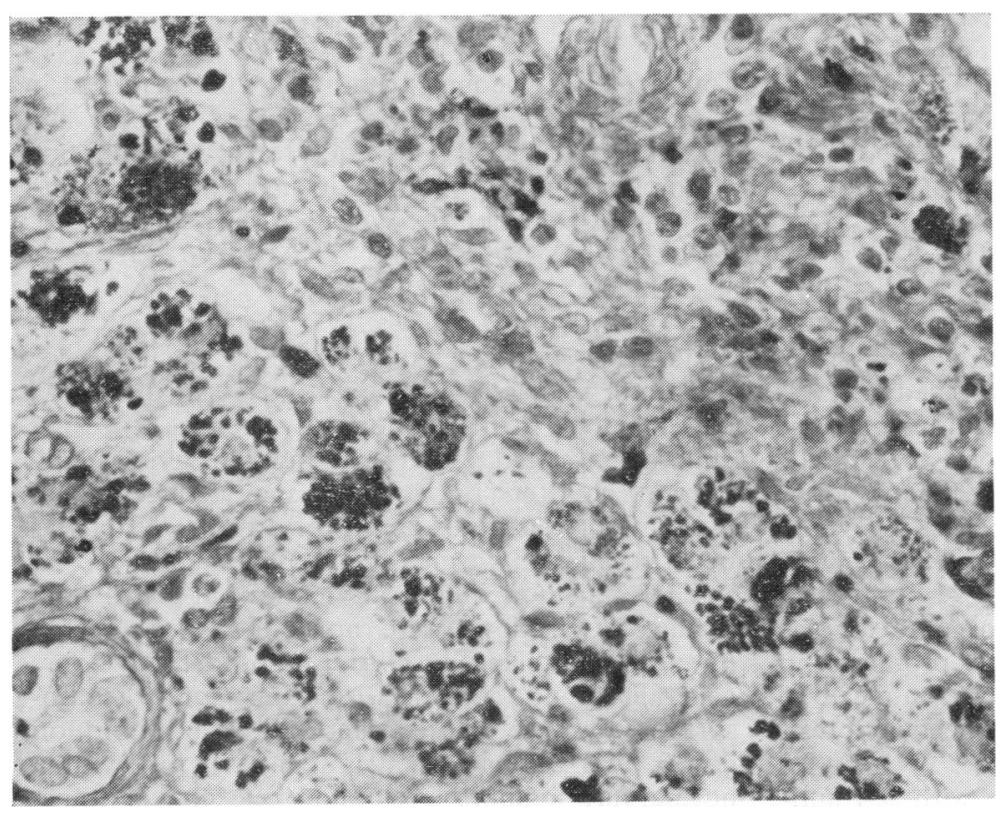

Figure Periodic acid-Schiff-positive droplets accumulating within distended hepatocytes adjacent to a prominent portal tract. The droplets measured up to $9 \mu \mathrm{m}$; droplets over $3 \mu \mathrm{m}$ in diameter are considered specific markers for the presence of a PiZ allele. 
neonatal hepatitis of prenatal onset, and has persisting hepatosplenomegaly. Neonatal hepatitis is associated with $\alpha$-1-antitrypsin deficiency in 10 to $20 \%$ of cases, the majority being homozygous for the $\mathrm{Z}$ allele. The $\mathrm{Z}^{-}$phenotype can be distinguished only by examination of the parental phenotypes.

The occurrence of neonatal hepatitis in our patient suggests that while low levels of plasma antiprotease are a factor in the aetiology of liver damage, such damage can occur without the presence of two $\mathrm{Z}$ alleles. Many individuals deficient in antiprotease activity have normal liver function however, so one or more other factors must be involved.

One may speculate on the nature of the second factor. It is not the PAS-positive deposits. ${ }^{5}$ Their presence and distribution show no correlation with liver damage. The limited family data suggest that $\mathrm{ZZ}$ individuals are at much greater risk of liver damage if a $\mathrm{ZZ}$ sibling has had liver disease, but the observation of monozygotic twins with the $\mathrm{ZZ}$ phenotype being discordant for liver disease is against the second factor being a separate gene defect. ${ }^{6}$ Attempts to identify infective or other environmental agents have not been successful. A further possibility is that low levels of $\alpha-1$-antitrypsin predispose, in some way, to immune damage to the fetal or neonatal liver. This is supported by the observation that lymphocytes from individuals with hepatitis and antiprotease deficiency are cytotoxic for isolated rabbit hepatocytes. ${ }^{7}$ As there is evidence that maternal lymphocytes enter the fetal circulation, ${ }^{8}$ these could become similarly sensitised; this would provide an explanation for the increased incidence of liver damage in $\alpha$-1-antitrypsindeficient individuals whose previous sibling was affected.
We thank Dr D W Hide and Professor Otto Wolff for permission to report this case, Miss P Goffron for preparing the manuscript, and Dr A Milford Ward and the staff of the Supraregional Specific Protein Reference Unit, for performing the $\alpha-1$ antitrypsin electrophoresis and quantitation.

\section{References}

1 Talamo R C, Langley C R E, Reed C E, Makino S. Alpha 1-antitrypsin deficiency: a variant with no detectable alpha 1-antitrypsin. Science $1973 ; 181$ : 70-1.

2 Martin J P, Vandeville D, Ropartz C. Letter: Alpha 1antitrypsin deficiency: PiO. Lancet 1973; ii: 845.

3 Bernheim J L, Arnaud P, Cellier C, Pokroy N, Traeger J. Apparent total alpha 1-antitrypsin deficiency-report of a case. Isr J Med Sci 1976; 12: 678-85.

4 Sveger T. Liver disease in alpha 1-antitrypsin deficiency detected by screening 200,000 infants. N Engl J Med 1976; 294: 1316-21.

${ }^{5}$ Eriksson S, Larsson C, Sveger T. Alpha 1-antitrypsin deficiency and disease. In: Boström $\mathbf{H}$, Ljungstedt $\mathbf{N}$, eds. Congenital diseases in childhood. Medical and sociomedical aspects. Skandia International Symposia; 12. Stockholm: Almqvist \& Wiksell, 1980: 70-91.

- Psacharopoulos H T, Mowat A P, Cook P J L, Rodeck C. Familial factors and the severity of liver disease in genetic deficiency of alpha-1 antitrypsin (PiZZ) (abstract). Arch Dis Child 1981; 56: 803-4.

7 Smith A L, Cochrane A M G, Mowat A P, Eddleston A W L F, Williams R. Cytotoxicity to isolated rabbit hepatocytes by lymphocytes from children with liver disease. J Pediatr 1977; 91 : 584-9.

8 Schroder J. Transplacental passage of blood cells. J Med Genet 1975; 12: 230-42.

Correspondence to Dr John Burn, MRC Clinical Genetics Unit, Institute of Child Health, 30 Guilford Street, London WC1N 1EH.

Received 26 November 1981
SUMMARY About half of all infants and toddlers with infectious diarrhoea of probable virus aetiology and treated with an oral rehydration solution containing $4.6 \%$ glucose had faecal glucose $\geqslant 0.3 \%$. In most of them the faecal concentration of glucose was higher than $0.50 \%$. From the physiological point of view, it seems wise to decrease the glucose concentration substantially from that so often recommended for the treatment of diarrhoea in developed countries.
The use of oral rehydration solutions in the treatment of diarrhoea in infants and toddlers has been successful. The precise composition of an ideal oral fluid is unknown. Solutions with a low glucose (2\%) and a high sodium concentration (about 90 $\mathrm{mmol} / \mathrm{l})$ are recommended for developing countries, but in developed countries such solutions generally contain 4-5\% glucose (or sucrose) and $25-35 \mathrm{mmol} / 1$ sodium. ${ }^{1}$ The higher incidence of toxigenic infections in developing countries is one reason for the difference, but the traditional fear of hyperosmolar 